\title{
God Is Never Ashamed of Us
}

\author{
Xuan Carlos Espinoza-Cuellar
}

Abstract A youth is curious about why his grandfather, who helped raise him, attends church in a particular way.

My abuelo (grandfather) is a kind man

Olive skin

Curly hair

My grandpa said "ask me anything"

So I asked

My abuelo taught me how to walk

How to feed squirrels

One day we went to church

He was wearing huaraches (leather sandals)

And I asked him

"Why don't you wear shoes instead?"

"Because I'm going to the house of god, and he sees us as we are-poor, brown, Indian, fat-God is never ashamed of us."

X. C. Espinoza-Cuellar $(\bowtie)$

University of Nevada Las Vegas, Las Vegas, NV, USA

(C) The Author(s), under exclusive license to Springer Nature Switzerland AG 2021

A. R. Del Castillo, G. Güido (eds.), Fathers, Fathering, and Fatherhood, Palgrave Studies in Literary Anthropology, https://doi.org/10.1007/978-3-030-60877-4_29 